DE

M E D I C I N A

T R O P I C A L

$\mathrm{DE}$

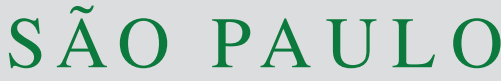

JOURNAL OF THE SÃO PAULO INSTITUTE OF TROPICAL MEDICINE

'These authors have contributed equally to this work

${ }^{1}$ Universidade Federal de Alagoas, Instituto de Ciências Biológicas e da Saúde, Laboratório de Pesquisas em Virologia e Imunologia, Grupo de Pesquisa em Regulação da Resposta Imune, Maceió Alagoas, Brazil

${ }^{2}$ Universidade Federal de Alagoas, Faculdade de Medicina, Maceió, Alagoas, Brazil

${ }^{3}$ Universidade Federal de Alagoas, Instituto de Computação, Laboratório de Computação Científica e Análise Numérica, Maceió, Alagoas, Brazil

${ }^{4}$ Universidad Nacional de La Rioja, Departamento de Ciencias de la Salud, La Rioja, Argentina

${ }^{5}$ Universidade Estadual de Ciências da Saúde de Alagoas, Hospital Escola Dr. Hélvio Auto, Maceió, Alagoas, Brazi

${ }^{6}$ Centro Universitário CESMAC, Maceió, Alagoas, Brazil

Correspondence to: Ênio José Bassi Universidade Federal de Alagoas, Instituto de Ciências Biológicas e da Saúde, Laboratório de Pesquisas em Virologia e Imunologia, Grupo de Pesquisa em Regulação da Resposta Imune, Av. Lourival Melo Mota, $\mathrm{s} / \mathrm{n}$, Cidade Universitária, 57072-900, Maceió, AL, Brazil

E-mail: enio.bassi@icbs.ufal.br

Received: 2 December 2019

Accepted: 23 March 2020

\section{Retrospective clinical and epidemiological analysis of scorpionism at a referral hospital for the treatment of accidents by venomous animals in Alagoas State, Northeast Brazil, 2007-2017}

\begin{abstract}
Jamile Taniele-Silva ${ }^{1 *}$, Lycia Gama Martins ${ }^{1,2,5^{*}}$, Marília Barroso de Sousa ${ }^{2}$, Letícia Moreira de Souza², Rodolfo Mathias Barros Cardoso², Santiago René Unda Velasco ${ }^{1}$, Geymerson dos Santos Ramos ${ }^{3}$, Cláudio Torres de Miranda ${ }^{\circledR 2}$, Adriana Ávila Moura ${ }^{2,5}$, Letícia Anderson ${ }^{(1,6}$, Ênio José Bassi ${ }^{\left({ }^{1} 1\right.}$
\end{abstract}

\section{ABSTRACT}

Scorpionism has a high incidence rate in Brazil. It is considered a serious public health problem mainly in tropical and subtropical regions around the world. The number of scorpion accidents have increased over the years and the highest frequencies have been reported mainly in the Brazilian Northeast region. Therefore, in this study we report a retrospective clinical and epidemiological analysis of scorpion stings from 2007 to 2017 in Alagoas State, Northeast Brazil, at a referral hospital for assistance and treatment of accidents by venomous animals. During the analyzed period, the referral hospital treated 27,988 cases, and an increase in the number of cases has taken place over the years. The highest frequency of scorpion stings was observed in females, and the age range most affected was from 20 to 29 years old. The most stung body site was the foot, followed by finger, toe or hand. Regarding the severity, most severe cases were reported in children up to 4 years old (69.4\%) and 50\% of the total cases treated with serotherapy corresponded to patients in this age range. Interestingly, it was also found that the occurrence of systemic manifestations and the severity of the cases were significantly associated with pediatric patients. In this way, this study highlights the scorpionism as an environmental public health problem in Alagoas State, Northeast Brazil, as well as the need to intensify the epidemiological surveillance and educational campaigns to prevent and control scorpion accidents throughout the year.

KEYWORDS: Scorpionism. Scorpion stings. Tropical medicine. Epidemiology.

\section{INTRODUCTION}

Scorpionism is a serious public health problem reaching high incidence rates and severity mainly in tropical and subtropical regions around the world ${ }^{1,2}$. In Brazil, scorpionism has a high incidence rate due to the wide distribution of scorpions in all the regions and ecosystems of the country ${ }^{3}$. The species of the genus Tityus, mainly Tityus serrulatus known as "yellow scorpion" due to its coloring, is considered the most dangerous scorpion and accounts for the highest number of accidents ${ }^{2,4}$.

Scorpion toxin is composed of a complex mixture of low molecular weight proteins that prolong depolarization of post-ganglionic nerve endings throughout the body, leading to a massive release of neurotransmitters, which trigger the predominance of systemic effects (adrenergic and/or cholinergic) ${ }^{5}$. Additionally, it is known that the mediators of the inflammatory response and toxicity on 
the cardiac fibers are involved in the genesis of the pulmonary edema due to the increase of permeability of the capillaries ${ }^{6}$.

Local pain is present in almost all the cases, with different levels of intensity and irradiation being reported as a pricking or burning sensation. Other local symptoms may be present, such as hyperemia, paresthesia, hyperesthesia, edema, sweating and piloerection ${ }^{2}$. Furthermore, systemic manifestations may occur and are more frequent in children, usually appearing hours after the accident ${ }^{1}$.

Scorpion envenomation cases may be classified as mild, moderate, or severe: 1) Mild cases have local signs, such as pain, erythema and local paraesthesia; 2) Moderate cases have sweating, nausea, occasional vomiting, tachycardia, agitation and mild arterial hypertension; 3) In severe cases, besides showing the signs and symptoms of mild and moderate cases, the patient also shows excessive sweating, profuse and incoercible vomiting, prostration, bradycardia, acute pulmonary edema and shock ${ }^{1,7,8}$. Moreover, complications such as acute pulmonary edema, shock or multiple organ failure are related to mortality ${ }^{7}$. The severity of clinical manifestations depends on the scorpion features (species, size and amount of venom injected) and victim factors (age, body weight and health status) ${ }^{1}$. The risk group for a poor prognosis includes mainly children under 5 years of age ${ }^{9}$ and the clinical outcome may be negatively influenced by the long period from the time of sting to the medical care ${ }^{1}$.

Epidemiology study of scorpionism in Brazil, from the years 2000 to 2012, reported 482,616 accidents and 728 deaths which shows an increase of $323 \%$ in the incidence rate between the first and last year of the study ${ }^{10}$. Comparing the Brazilian regions, the Northeast had the highest annual incidence and mortality rates. Alagoas State had the highest average annual incidence rate $(105.9 / 100,000 \text { inhabitants })^{10}$. However, although it is a serious public health problem, the epidemiology of scorpionism remains underreported $\mathrm{d}^{1,2}$ and until the present moment, there is no study analyzing cases of scorpion accidents solely in Alagoas State. Therefore, in this study we report a retrospective analysis of the clinical and epidemiological profile of scorpion stings at the referral Hospital for Assistance and Treatment of accidents by venomous animals in Alagoas, Northeast of Brazil, in the period from 2007 to 2017.

\section{MATERIAL AND METHODS}

The Alagoas State is in Northeast Brazil with an area of $27,767 \mathrm{~km}^{2}$ and comprises 102 municipalities ${ }^{11,12}$. These municipalities are grouped into three mesoregions (East, Agreste and Sertao) ${ }^{12}$. The East mesoregion covers the coast and the forest zone, where the capital Maceio is located $^{11}$. On the coast and in the forest zone, the annual range of rainfall levels is between 1,300 to $1,600 \mathrm{~mm}$ and the maximum annual average air temperature in this region fluctuates between 30 and $31{ }^{\circ} \mathrm{C}^{11}$.

According to the 2010 Brazilian census, the resident population in Alagoas State is 3,120,494 inhabitants, composed of $48.5 \%$ men and $51.5 \%$ women $^{12}$. Maceio is the State capital and most populous city, where $29.9 \%$ of the population resides ${ }^{12}$.

In this study, the scorpionism cases were analyzed at a Referral Hospital for the Assistance and Treatment of venomous animals' accidents in Alagoas State, located in Maceio, and occurred from January 1, 2007 to December 31, 2017. The cases of accidents caused by venomous animals in Brazil are of compulsory notification thus being reported in notification forms and recorded in the SINAN (Sistema de Informacao de Agravos de Notificacao) database. Data were obtained from the TabWin version 3.6b software platform (Ministerio da Saude, Brasilia, DF, Brazil) from SINAN, a public domain database. It was based solely on secondary data, without access to the patients' nominal data or anything else that could lead to identification; therefore, ensuring the confidentiality of the information collected. All the ethical and legal requirements were followed as specified by Resolution $N^{\circ} 466 / 12$ from the National Health Council (CNS) of Brazil.

The software Microsoft Excel 2010 was used to register collected data and the demographic information was obtained from the 2010 census of the Brazilian Institute of Geography and Statistics (IBGE) ${ }^{12}$.

The fields of the SINAN Notification Form (SNF) for accidents with venomous animals are available as Supplementary Material. The variables analyzed in this study were: date of accident, gender (female or male), patient's age, skin color/ethnicity (white, black, Asian, multiracial or indigenous), accident zone (urban, peri-urban or rural), occupation, education level (based on Brazilian law and guidelines), body site of the scorpion sting, severity classification (mild, moderate or severe), local manifestations, systemic manifestations, time between the sting and the medical care, and treatment with serotherapy.

The linear regression analysis ${ }^{13}$ for the number of cases over the years was performed using $\mathrm{R}$ version 3.4.4 (R Core Team, Vienna, Austria). The Student's t-test (unpaired samples) ${ }^{14}$ was performed to compare the number of cases between male and female groups. The Analysis of Variance (ANOVA) one-way ${ }^{15}$ with Tukey's multiple comparisons test ${ }^{16}$ was used to establish whether there is a difference among the months by using the Graph-Pad Prism 6.00 (GraphPad Software, La Jolla, CA, USA). 
The observed cases of demographic variables were compared to the frequencies from Alagoas' population, obtained from the 2010 Brazilian census $^{12}$, by applying the Pearson's Chi-square Goodness-of-Fit test ${ }^{17}$ or Binomial Test $^{18}$ by using the GraphPad Prism version 6 software, as detailed in the Supplementary Material.

In order to evaluate the association between the occurrence of systemic clinical manifestations and the most frequent sociodemographic and clinical characteristics, the Pearson's chi-square test for independence ${ }^{19}$ was performed using the IBM SPSS Statistics for Windows version 23.0 (IBM Corp., Armond, NY, USA). Some variables were not included because they did not meet the test assumption that no more than $20 \%$ of the expected counts are less than 5 and all individual expected counts are 1 or greater $^{20}$ (Supplementary Material). The level of significance was $\mathrm{p}<0.05$.

\section{RESULTS}

In this retrospective study, from 2007 to 2017, the Referral Hospital for the Assistance and Treatment of Accidents by Venomous Animals in Alagoas State, Brazil, attended 27,988 cases of scorpion stings. During this period, Alagoas State registered 63,762 cases in the SINAN database, with an average incidence rate of 177.4/100,000 inhabitants. Hence, the data collected at a referral hospital represents $44 \%$ of the total cases reported in the State. The analysis over the years showed an increase in the number of scorpion sting cases $(\beta=0.73 ; p<0.01)$ (Figure $1 \mathrm{~A})$. It is worth mentioning that cases of scorpionism occurred throughout the year and no significant difference among the months was observed in the analyzed period $(p=0.4977)$ (Figure 1B).

Of the total $(n=27,988)$, the number of cases were higher in females compared to males (Female $=61.8 \%$ vs Male $=38.2 \%$ ) and the average number of cases per year was significant between different genders $($ male $=972.5 \pm 53.6$ vs female $=1575.0 \pm 97.4$; mean \pm SEM; $\mathrm{p}<0.0001)$.

The highest frequency of sting cases occurred in the group of 20-29 years old (16.9\%), as shown in Table 1. Regarding the geographic distribution, the urban area presented the highest frequency of cases $(n=26,494$; $94.7 \%$ ), while the number of cases in the peri-urban and rural areas accounted for less than $2 \%$ of all the cases (Table 1). In this study, the multiracial group was the most representative $88.8 \%$ of the cases $(\mathrm{n}=24,858)$, followed by the white group $(\mathrm{n}=1,426 ; 5.1 \%)$, the black group $(\mathrm{n}=1,243 ; 4.4 \%)$, the indigenous group $(\mathrm{n}=25 ; 0.1 \%)$ and the Asian group ( $\mathrm{n}=16 ; 0.1 \%)$ (Table 1). It is important
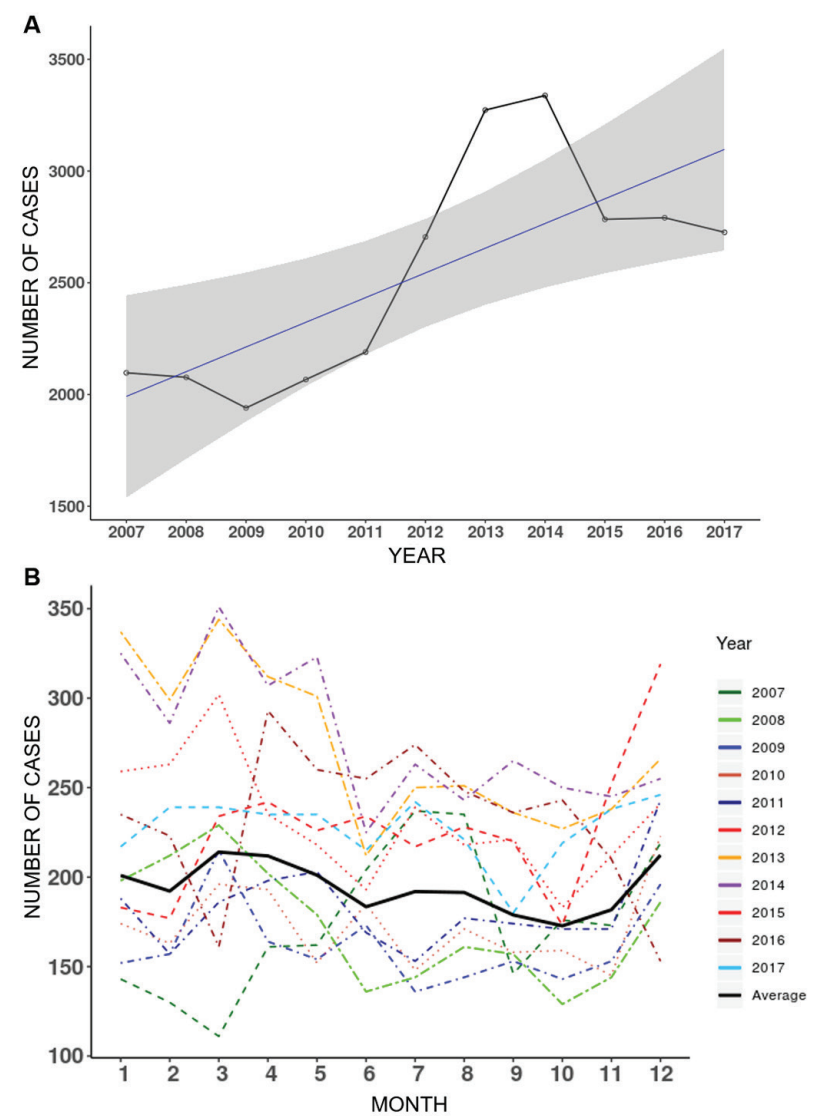

Figure 1 - Temporal distribution of scorpionism cases treated at the referral hospital for the assistance and treatment of accidents by venomous animals in Alagoas State, Northeast of Brazil, from 2007 to 2017. A) Absolute number of scorpionism cases per year (black line) analyzed by a linear regression model (blue line) $(\beta=0.73 ; p<0.01)$; $B)$ Absolute number of scorpionism cases distributed by month of the accident.

to emphasize that the discrepancy between the distribution of scorpion sting cases considering demographic variables (gender, age range, skin color/ethnicity and accident zone) is significantly different $(\mathrm{p}<0.0001)$ from the population frequencies of Alagoas State (Supplementary Material). Furthermore, considering the education level, the highest number of cases occurred in the group that completed high school ( $\mathrm{n}=5,859 ; 20.9 \%)$ (Table 1$)$.

The professional occupation was recorded in $71.6 \%$ $(n=20,042)$ of the cases in the SNF. Of them, 32\% were students, followed by housewives $(21.5 \%)$ and retirees/ pensioners (8.4\%). Among the female victims, most of them were housewives ( $n=4,263 ; 32.7 \%$ ), followed by students $(\mathrm{n}=3,425 ; 26.3 \%)$ and retirees/pensioners $(\mathrm{n}=1,204$; $9.3 \%)$. In the male group, most were students $(\mathrm{n}=2,554$; $36.4 \%)$, followed by retirees/pensioners $(\mathrm{n}=479,6.8 \%)$ and bricklayers $(\mathrm{n}=307 ; 4.4 \%)$. However, it is worth mentioning that only $0.7 \%$ of all scorpion sting cases were reported as work-related accidents in the SNF. 
Table 1 - Distribution of scorpion sting cases at the referral hospital for the assistance and treatment of accidents by venomous animals in Alagoas State, Northeast of Brazil, from 2007 to 2017, according to the gender, age, accident zone, skin color/ethnicity and education level of patients.

\begin{tabular}{|c|c|c|c|c|c|c|c|}
\hline \multirow{3}{*}{\multicolumn{2}{|c|}{ Sociodemographic characteristics }} & \multicolumn{4}{|c|}{ Gender } & \multirow{2}{*}{\multicolumn{2}{|c|}{ Total }} \\
\hline & & \multicolumn{2}{|c|}{ Female } & \multicolumn{2}{|c|}{ Male } & & \\
\hline & & $\mathbf{N}$ & $\%$ & $\mathbf{N}$ & $\%$ & $\mathbf{N}$ & $\%$ \\
\hline \multirow{12}{*}{ Age Range in years } & $<1$-year-old & 79 & 0.5 & 78 & 0.7 & 157 & 0.6 \\
\hline & $1-$ to 4 & 1,030 & 6.0 & 1,049 & 9.8 & 2,079 & 7.4 \\
\hline & 5- to 9 & 1,216 & 7.0 & 1,183 & 11.1 & 2,399 & 8.6 \\
\hline & $10-$ to 14 & 1,234 & 7.1 & 1,056 & 9.9 & 2,290 & 8.2 \\
\hline & 15- to 19 & 1,377 & 8.0 & 980 & 9.2 & 2,357 & 8.4 \\
\hline & $20-$ to 29 & 2,909 & 16.8 & 1,833 & 17.1 & 4,742 & 16.9 \\
\hline & $30-$ to 39 & 2,682 & 15.5 & 1,474 & 13.8 & 4,156 & 14.8 \\
\hline & $40-$ to 49 & 2,384 & 13.8 & 1,230 & 11.5 & 3,614 & 12.9 \\
\hline & $50-$ to 59 & 2,017 & 11.7 & 865 & 8.1 & 2,882 & 10.3 \\
\hline & $60-$ to 69 & 1,390 & 8.0 & 583 & 5.5 & 1,973 & 7.0 \\
\hline & $70-$ to 79 & 717 & 4.1 & 269 & 2.5 & 986 & 3.5 \\
\hline & $\geq 80$-years & 260 & 1.5 & 93 & 0.9 & 353 & 1.3 \\
\hline \multirow{4}{*}{ Accident zone } & Urban & 16,420 & 94.9 & 10,074 & 94.2 & 26,494 & 94.7 \\
\hline & Peri-urban & 128 & 0.7 & 98 & 0.9 & 226 & 0.8 \\
\hline & Rural & 138 & 0.8 & 125 & 1.2 & 263 & 0.9 \\
\hline & Ignored/Omitted & 609 & 3.5 & 396 & 3.7 & 1,005 & 3.6 \\
\hline \multirow{6}{*}{ Skin color/Ethnicity } & White & 921 & 5.3 & 505 & 4.7 & 1,426 & 5.1 \\
\hline & Black & 745 & 4.3 & 498 & 4.7 & 1,243 & 4.4 \\
\hline & Asian & 10 & 0.1 & 6 & 0.1 & 16 & 0.1 \\
\hline & Multiracial & 15,332 & 88.6 & 9,526 & 89.1 & 24,858 & 88.8 \\
\hline & Indigenous & 15 & 0.1 & 10 & 0.1 & 25 & 0.1 \\
\hline & Ignored/Omitted & 272 & 1.6 & 148 & 1.4 & 420 & 1.5 \\
\hline \multirow{11}{*}{ Educational level } & Unlettered & 654 & 3.8 & 269 & 2.5 & 923 & 3.3 \\
\hline & Uncomplete primary school & 1,555 & 9.0 & 1,079 & 10.1 & 2,634 & 9.4 \\
\hline & Complete primary school & 857 & 5.0 & 484 & 4.5 & 1,341 & 4.8 \\
\hline & Uncomplete middle school & 2,571 & 14.9 & 1,740 & 16.3 & 4,311 & 15.4 \\
\hline & Complete middle school & 1,448 & 8.4 & 858 & 8.0 & 2,306 & 8.2 \\
\hline & Uncomplete high school & 970 & 5.6 & 563 & 5.3 & 1,533 & 5.5 \\
\hline & Complete high school & 3,907 & 22.6 & 1,952 & 18.3 & 5,859 & 20.9 \\
\hline & Uncomplete higher education & 465 & 2.7 & 319 & 3.0 & 784 & 2.8 \\
\hline & Complete higher education & 1,135 & 6.6 & 513 & 4.8 & 1,648 & 5.9 \\
\hline & Not applicable & 2,174 & 12.6 & 1,309 & 12.2 & 3,483 & 12.4 \\
\hline & Ignored/Omitted & 1,559 & 9.0 & 1,607 & 15.0 & 3,166 & 11.3 \\
\hline
\end{tabular}

Regarding the severity classification, $98.1 \%(n=27,469)$ of the cases were classified as mild, while just a few cases were classified as moderate $(\mathrm{n}=381 ; 1.4 \%)$ or severe $(\mathrm{n}=98 ; 0.4 \%)$ (Table 2). Local (LM) and systemic (SM) manifestations were reported in 95.4\% $(\mathrm{n}=26,707)$ and $1.9 \%(n=525)$ of the cases, respectively. The most frequent
LM was local pain (98.3\%) and the most frequent SM was vagal hyperactivity manifestations $(60.6 \%)$, including nausea and vomiting. We observed an association between the occurrence of SM and the patient's age $(\mathrm{p}<0.001)$, in most cases $(61.2 \%)$ detected in patients up to 9 years of age. In addition, the association between age and severity 
Table 2 - Distribution of clinical characteristics of scorpion sting cases at the referral hospital for the assistance and treatment of accidents by venomous animals in Alagoas State, Northeast of Brazil, from 2007 to 2017, according to the severity, sting location, local and systemic manifestations and serotherapy.

\begin{tabular}{|c|c|c|c|c|c|c|c|}
\hline \multirow{3}{*}{ Clinical Characteristics } & & \multicolumn{4}{|c|}{ Gender } & \multirow{2}{*}{\multicolumn{2}{|c|}{ Total }} \\
\hline & & \multicolumn{2}{|c|}{ Female } & \multicolumn{2}{|c|}{ Male } & & \\
\hline & & $\mathrm{N}$ & $\%$ & N & $\%$ & $\mathbf{N}$ & $\%$ \\
\hline \multirow{4}{*}{ Severity } & Mild & 16,998 & 98.3 & 10,471 & 97.9 & 27,469 & 98.1 \\
\hline & Moderate & 225 & 1.3 & 156 & 1.5 & 381 & 1.4 \\
\hline & Severe & 54 & 0.3 & 44 & 0.4 & 98 & 0.4 \\
\hline & Ignored/omitted & 18 & 0.1 & 22 & 0.2 & 40 & 0.1 \\
\hline \multirow{11}{*}{ Sting location } & Head & 151 & 0.9 & 139 & 1.3 & 290 & 1.0 \\
\hline & Arm & 491 & 2.8 & 348 & 3.3 & 839 & 3.0 \\
\hline & Forearm & 336 & 1.9 & 289 & 2.7 & 625 & 2.2 \\
\hline & Hand & 1,715 & 9.9 & 1,197 & 11.2 & 2,912 & 10.4 \\
\hline & Finger & 3,105 & 18.0 & 2,079 & 19.4 & 5,184 & 18.5 \\
\hline & Torso & 753 & 4.4 & 598 & 5.6 & 1,351 & 4.8 \\
\hline & Leg & 614 & 3.6 & 440 & 4.1 & 1,054 & 3.8 \\
\hline & Thigh & 490 & 2.8 & 423 & 4.0 & 913 & 3.3 \\
\hline & Foot & 5,373 & 31.1 & 2,717 & 25.4 & 8,090 & 28.9 \\
\hline & Toe & 2,690 & 15.6 & 1,399 & 13.1 & 4,089 & 14.6 \\
\hline & Ignored/Omitted & 1,577 & 9.1 & 1,064 & 10.0 & 2,641 & 9.4 \\
\hline \multirow{3}{*}{ Local manifestations } & Yes & 16,592 & 95.9 & 10,115 & 94.6 & 26,707 & 95.4 \\
\hline & No & 537 & 3.1 & 446 & 4.2 & 983 & 3.5 \\
\hline & Ignored/omitted & 166 & 1.0 & 132 & 1.2 & 298 & 1.1 \\
\hline \multirow{3}{*}{ Systemic manifestations } & Yes & 327 & 1.9 & 198 & 1.9 & 525 & 1.9 \\
\hline & No & 16,828 & 97.3 & 10,404 & 97.3 & 27,232 & 97.3 \\
\hline & Ignored/omitted & 140 & 0.8 & 91 & 0.9 & 231 & 0.8 \\
\hline \multirow{3}{*}{ Serotherapy } & Yes & 272 & 1.6 & 186 & 1.7 & 458 & 1.6 \\
\hline & No & 16,999 & 98.3 & 10,480 & 98.0 & 27,479 & 98.2 \\
\hline & Ignored/omitted & 24 & 0.1 & 27 & 0.3 & 51 & 0.2 \\
\hline
\end{tabular}

was significant $(\mathrm{p}<0.001)$ (Supplementary Material), in which $59.3 \%$ of the moderate and $83.7 \%$ of the severe cases occurred in the group up to 9 years of age (Table 3). It is important to emphasize that in the group of children up to 4 years old, $69.4 \%$ were classified as severe cases, and from the total cases treated with serotherapy, $50 \%$ of them were in this age group (Table 4).

The analysis comparing the body sites of scorpion stings revealed a higher frequency in the foot $(28.9 \%)$, followed by the finger (18.5\%), the toe (14.6\%) and the hand (10.4\%) (Table 3). In addition, the frequency distribution of the stung body site was very similar for both male and female groups (Figure 2). Considering the case severity, the most common body sites were the foot, finger, and toe in the mild and moderate cases. However, in the severe cases, the most commonly stung site was also the foot $(27.6 \%)$, followed by both the hand and toe with the same frequencies (both at $13.3 \%$ ) (Table 3 ).

Considering the time between the scorpion sting and the medical care assistance, $56.6 \%$ of all the cases were treated at the hospital within the first hour after the accident (Table 3), and an association was detected between the occurrence of systemic manifestations (SM) and the time elapsed until medical care $(\mathrm{p}<0.001)$ (Supplementary Material). In addition, SM were not observed in $64.2 \%$ of the cases which were treated up to one hour after the accident, therefore suggesting that a faster medical assistance after a scorpion sting contributes to a better prognosis.

The serotherapy was administered to $1.6 \%$ of all the cases, of which, $78.5 \%$ of the moderate cases and $89.8 \%$ of the severe cases were treated with anti-scorpion venom serum (Table 3). 
Table 3 - Distribution of scorpion sting cases according to the severity considering the age range, sting location, the time between the sting and the medical care after the incident and serotherapy reported at the referral hospital for the assistance and treatment of accidents by venomous animals in Alagoas State, Northeast of Brazil, from 2007 to 2017.

\begin{tabular}{|c|c|c|c|c|c|c|c|c|c|c|c|}
\hline & & \multicolumn{10}{|c|}{ Severity } \\
\hline & & \multicolumn{2}{|c|}{ Mild } & \multicolumn{2}{|c|}{ Moderate } & \multicolumn{2}{|c|}{ Severe } & \multicolumn{2}{|c|}{ Ignored/omitted } & \multicolumn{2}{|c|}{ Total } \\
\hline & & $\mathrm{N}$ & $\%$ & $\mathrm{~N}$ & $\%$ & $\mathrm{~N}$ & $\%$ & $\mathrm{~N}$ & $\%$ & $\mathrm{~N}$ & $\%$ \\
\hline \multirow{12}{*}{$\begin{array}{l}\text { Age Range } \\
\text { (years) }\end{array}$} & $<1$-year-old & 126 & 0.5 & 21 & 5.5 & 10 & 10.2 & 0 & 0.0 & 157 & 0.6 \\
\hline & 1- to 4 & 1,877 & 6.8 & 140 & 36.7 & 58 & 59.2 & 4 & 10.0 & 2,079 & 7.4 \\
\hline & 5- to 9 & 2,318 & 8.4 & 65 & 17.1 & 14 & 14.3 & 2 & 5.0 & 2,399 & 8.6 \\
\hline & $10-$ to 14 & 2,269 & 8.3 & 15 & 3.9 & 0 & 0.0 & 6 & 15.0 & 2,290 & 8.2 \\
\hline & 15- to 19 & 2,341 & 8.5 & 12 & 3.1 & 1 & 1.0 & 3 & 7.5 & 2,357 & 8.4 \\
\hline & $20-$ to 29 & 4,706 & 17.1 & 27 & 7.1 & 1 & 1.0 & 8 & 20.0 & 4,742 & 16.9 \\
\hline & $30-$ to 39 & 4,122 & 15.0 & 25 & 6.6 & 4 & 4.1 & 5 & 12.5 & 4,156 & 14.8 \\
\hline & $40-$ to 49 & 3,587 & 13.1 & 17 & 4.5 & 6 & 6.1 & 4 & 10.0 & 3,614 & 12.9 \\
\hline & $50-$ to 59 & 2,847 & 10.4 & 29 & 7.6 & 0 & 0.0 & 6 & 15.0 & 2,882 & 10.3 \\
\hline & $60-$ to 69 & 1,955 & 7.1 & 15 & 3.9 & 1 & 1.0 & 2 & 5.0 & 1,973 & 7.0 \\
\hline & $70-$ to 79 & 972 & 3.5 & 13 & 3.4 & 1 & 1.0 & 0 & 0.0 & 986 & 3.5 \\
\hline & $\geq 80$-years & 349 & 1.3 & 2 & 0.5 & 2 & 2.0 & 0 & 0.0 & 353 & 1.3 \\
\hline \multirow{11}{*}{ Sting Location } & Head & 282 & 1.0 & 5 & 1.3 & 2 & 2.0 & 1 & 2.5 & 290 & 1.0 \\
\hline & Arm & 824 & 3.0 & 11 & 2.9 & 3 & 3.1 & 1 & 2.5 & 839 & 3.0 \\
\hline & Forearm & 615 & 2.2 & 9 & 2.4 & 1 & 1.0 & 0 & 0.0 & 625 & 2.2 \\
\hline & Hand & 2,849 & 10.4 & 46 & 12.1 & 13 & 13.3 & 4 & 10.0 & 2,912 & 10.4 \\
\hline & Finger & 5,106 & 18.6 & 62 & 16.3 & 9 & 9.2 & 7 & 17.5 & 5,184 & 18.5 \\
\hline & Torso & 1,340 & 4.9 & 6 & 1.6 & 3 & 3.1 & 2 & 5.0 & 1,351 & 4.8 \\
\hline & Leg & 1,045 & 3.8 & 6 & 1.6 & 2 & 2.0 & 1 & 2.5 & 1,054 & 3.8 \\
\hline & Thigh & 898 & 3.3 & 13 & 3.4 & 2 & 2.0 & 0 & 0.0 & 913 & 3.3 \\
\hline & Foot & 7,923 & 28.8 & 126 & 33.1 & 27 & 27.6 & 14 & 35.0 & 8,090 & 28.9 \\
\hline & Toe & 4,014 & 14.6 & 59 & 15.5 & 13 & 13.3 & 3 & 7.5 & 4,089 & 14.6 \\
\hline & Ignored/omitted & 2,573 & 9.4 & 38 & 10.0 & 23 & 23.5 & 7 & 17.5 & 2,641 & 9.4 \\
\hline \multirow{7}{*}{$\begin{array}{l}\text { Time between } \\
\text { the sting and } \\
\text { the medical } \\
\text { care }\end{array}$} & $<1$ hour & 15,604 & 56.8 & 166 & 43.6 & 39 & 39.8 & 22 & 55.0 & 15,831 & 56.6 \\
\hline & 1 to 3 hours & 5,022 & 18.3 & 91 & 23.9 & 33 & 33.7 & 5 & 12.5 & 5,151 & 18.4 \\
\hline & 3 to 6 hours & 1,515 & 5.5 & 32 & 8.4 & 11 & 11.2 & 2 & 5.0 & 1,560 & 5.6 \\
\hline & 6 to 12 hours & 1,130 & 4.1 & 16 & 4.2 & 4 & 4.1 & 2 & 5.0 & 1,152 & 4.1 \\
\hline & 12 to 24 hours & 759 & 2.8 & 23 & 6.0 & 2 & 2.0 & 1 & 2.5 & 785 & 2.8 \\
\hline & $>24$ hours & 298 & 1.1 & 11 & 2.9 & 1 & 1.0 & 0 & 0.0 & 310 & 1.1 \\
\hline & Ignored/omitted & 3,141 & 11.4 & 42 & 11.0 & 8 & 8.2 & 8 & 20.0 & 3,199 & 11.4 \\
\hline \multirow{3}{*}{ Serotherapy } & Yes & 69 & 0.3 & 299 & 78.5 & 88 & 89.8 & 2 & 5.00 & 458 & 1.6 \\
\hline & No & 27,365 & 99.6 & 81 & 21.3 & 9 & 9.2 & 24 & 60.0 & 27,479 & 98.2 \\
\hline & Ignored/omitted & 35 & 0.1 & 1 & 0.3 & 1 & 1.0 & 14 & 35.0 & 51 & 0.2 \\
\hline
\end{tabular}

\section{DISCUSSION}

Scorpion envenomation is one of the most serious health challenges in tropical and subtropical regions, and epidemiological research can identify factors attributed to scorpion stings which guide public health policies. In light of these, over the years, our study has shown an increase in the number of cases of scorpion stings treated at a referral hospital for the treatment of accidents by venomous animals in Alagoas State.

In a previous study conducted with SINAN data encompassing all Brazilian States in the years 2000 to 2012, 
Table 4 - Distribution of serotherapy administrated to the cases after the scorpion sting according to patients' age at the referral hospital for the assistance and treatment of accidents by venomous animals in Alagoas State, Northeast of Brazil, from 2007 to 2017.

\begin{tabular}{|c|c|c|c|c|c|c|c|c|}
\hline \multirow{3}{*}{ Age Range (years) } & \multicolumn{8}{|c|}{ Serotherapy } \\
\hline & \multicolumn{2}{|c|}{ Yes } & \multicolumn{2}{|c|}{ No } & \multicolumn{2}{|c|}{ Ignored/omitted } & \multicolumn{2}{|c|}{ Total } \\
\hline & $\mathrm{N}$ & $\%$ & $\mathrm{~N}$ & $\%$ & $\mathrm{~N}$ & $\%$ & $\mathrm{~N}$ & $\%$ \\
\hline$<1$ & 30 & 6.6 & 127 & 0.5 & 0 & 0.0 & 157 & 0.6 \\
\hline 1 - to 4 & 199 & 43.4 & 1,876 & 6.8 & 4 & 7.8 & 2,079 & 7.4 \\
\hline 5- to 9 & 83 & 18.1 & 2,314 & 8.4 & 2 & 3.9 & 2,399 & 8.6 \\
\hline $10-$ to 14 & 10 & 2.2 & 2,278 & 8.3 & 2 & 3.9 & 2,290 & 8.2 \\
\hline 15- to 19 & 12 & 2.6 & 2,338 & 8.5 & 7 & 13.7 & 2,357 & 8.4 \\
\hline $20-$ to 29 & 23 & 5.0 & 4,706 & 17.1 & 13 & 25.5 & 4,742 & 16.9 \\
\hline $30-$ to 39 & 24 & 5.2 & 4,124 & 15.0 & 8 & 15.7 & 4,156 & 14.8 \\
\hline $40-$ to 49 & 18 & 3.9 & 3,593 & 13.1 & 3 & 5.9 & 3,614 & 12.9 \\
\hline $50-$ to 59 & 28 & 6.1 & 2,846 & 10.4 & 8 & 15.7 & 2,882 & 10.3 \\
\hline $60-$ to 69 & 16 & 3.5 & 1,954 & 7.1 & 3 & 5.9 & 1,973 & 7.0 \\
\hline $70-$ to 79 & 11 & 2.4 & 975 & 3.5 & 0 & 0.0 & 986 & 3.5 \\
\hline$\geq 80$ & 4 & 0.9 & 348 & 1.3 & 1 & 2.0 & 353 & 1.3 \\
\hline
\end{tabular}

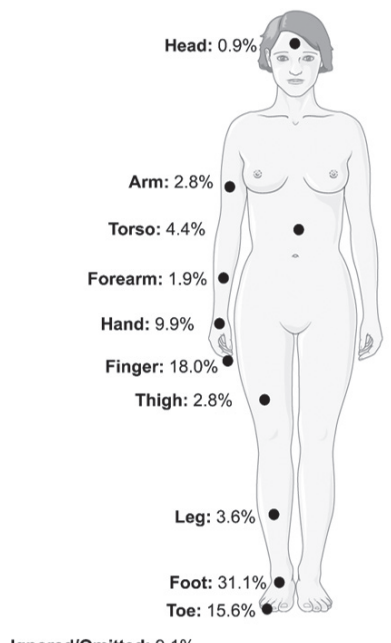

Ignored/Omitted: $9.1 \%$

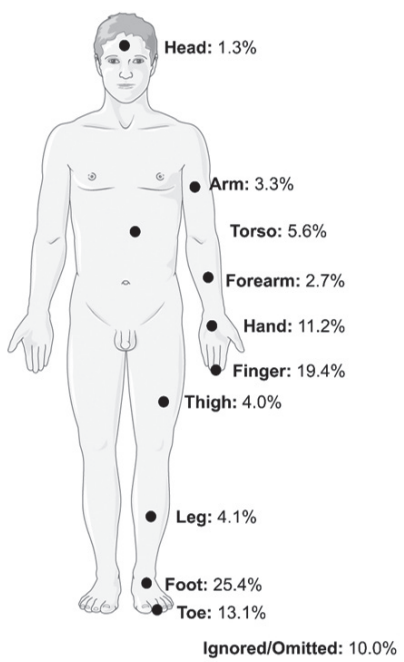

Figure 2 - Frequency distribution of body sites of scorpion stings cases treated at the referral hospital for the assistance and treatment of accidents by venomous animals in Alagoas State, Northeast of Brazil, from 2007 to 2017.

Alagoas presented the highest annual average incidence rate $^{10}$. When comparing with the period analyzed in our study, the rate increased more than $60 \%$, raising alarm to this public health problem. The literature points out that during the hottest and rainiest periods of the year there are the highest incidences of scorpion stings in Brazil ${ }^{21}$. However, we did not observe a significant difference in the number of cases of scorpion stings among the months in the analyzed period in Alagoas. This result can be explained by the slight temperature variations mainly in Maceio and the forest zone regions of Alagoas State ${ }^{11}$, which should have allowed the same level of scorpion activity throughout the year. In the same way, previous studies performed in the Northeast region of Brazil had also failed to detect significant differences in the number of cases over the months ${ }^{22,23}$.

The highest frequency of scorpion stings was observed in females compared to the male group of patients. These data corroborate results of other studies carried out in the Northeast region of Brazil ${ }^{22,24-26}$. This exposure relationship can be explained by the longer period of time that women usually stay in the home environment, compared to men, as previously reported ${ }^{27}$. The home environment is a shelter for scorpion feeding and proliferation, due to the abundant presence of synanthropic opportunistic arthropods which constitute its $\operatorname{diet}^{28}$. On the other hand, it is important to note that studies carried out in the Brazilian North, South and Southeast regions detected a higher incidence rate of scorpion stings in males, related to the exposure in the workplace ${ }^{29,30}$. Another fact that may explain the disparity among genders is probably the higher propensity to seek medical care by women. In this way, aspects of gender identity reinforced by cultural standards can influence those seeking medical treatment, therefore, resulting in the selfneglected care needed to maintain the quality of health ${ }^{31,32}$.

The patient's occupation highlights the home environment as a risky place for scorpion stings because most of the patients were students, housewives and retired/ pensioners. However, it is important to emphasize that, while the SNF provides a field for reporting occupational accidents, a field detailing the patient's activity at the time 
of the accident could better clarify and establish a more accurate relationship between exposure to risks.

The largest number of cases occurred in adult patients, corroborating other previous studies that highlighted this economically active population as the most susceptible to scorpion stings ${ }^{10,22,24,25}$. Moreover, the majority of the cases in this study occurred in urban areas, as previously reported in different regions of Brazil ${ }^{10,22,24,25}$. In this way, sociodemographics factors such as urbanization, high-density population, low-income population, poor housing conditions and lack of sanitation are determining factors for the increase in the number of cases of scorpionism ${ }^{3,30}$. In addition, the high density of the scorpion population can be justified by both, adaptations to the urban environment and the rapid spread of the scorpion species by parthenogenesis reproduction ${ }^{33}$.

Several body sites can be targeted by scorpions. In the present study, the majority of scorpion stings occurred on the lower limbs followed by upper limbs as reported in some studies ${ }^{24,34}$. Moreover, the foot was the most affected body site corresponding to $28.9 \%$ of all cases. In contrast, other studies carried out in other locations around Brazil, have detected the upper limbs as the most affected anatomical site ${ }^{22,30,35,36}$. It is important to emphasize that the extremities of the body are generally the most affected sites and are usually associated with routine activities such as wearing shoes without careful observation ${ }^{36}$.

The elapsed time between the sting and early medical treatment is a crucial factor that greatly influences the prognosis of scorpion accidents ${ }^{7}$, as our study revealed that approximately $75 \%$ of all the patients received medical treatment up to 3 hours after the accident, in accordance with other previous studies ${ }^{22-24,26,29}$. In addition, in pediatric patients, a known risk group for scorpionism ${ }^{9,37}$, it was shown that prompt medical care may result in a better prognosis and therefore in mild cases ${ }^{38}$. The observation that the majority of cases with moderate or severe cases was detected in the age group up to 9 years old highlights the need for additional care with pediatric patients. Moreover, the frequencies of moderate and severe cases observed in this age group were higher than those previously reported ${ }^{39,40}$. The severity of scorpion envenomation depends on several factors such as the anatomical location of the bite, age, weight, and health status of the victim ${ }^{1}$. In pediatric patients, both the lowest blood volume and the lowest total body volume contributed to the excessive concentration of scorpion venom in the plasma, favoring the manifestation of severe symptoms and consequently, a higher risk of death ${ }^{5,41}$.

The treatment with serotherapy is indicated only in moderate and severe cases ${ }^{7}$, and in consonance with this indication, we observed that the antitoxin sera was administered to $1.6 \%$ of the total cases; which is a result similar to the frequency reported by another epidemiological study in Brazil ${ }^{36}$.

In Brazil, accidents with venomous animals require a mandatory report, filling all the fields in the SNF, according to the Ministry of Health ${ }^{42}$. It is important to emphasize that certain data such as the education level, the occupational employment, sting location and time elapsed between the accident and the medical care were sometimes ignored and unfilled which undermines the epidemiological analysis. This lack of information has also been reported for other diseases with mandatory reporting ${ }^{43-45}$. Therefore, the awareness among healthcare professionals of the importance of completing the SNF ensures the integrity of the collected and reported data.

The SINAN data has the purpose of identifying priority areas, monitoring and evaluation ${ }^{46}$. Our study highlights the urgent necessity of public policies that promote monitoring and treatment, but mainly control strategies. In this sense, actions to prevent proliferation, through monitoring, control, management, and environmental education ${ }^{46}$ should be implemented by the State. For monitoring, it is necessary to use indicators that clarify the level and intensity of home infestations, which can be carried out by community health agents and/or endemic agents ${ }^{46}$. Some species of scorpions are adapted to human environments and play an important role in the ecological balance ${ }^{47}$. Therefore, the eradication of these species is neither possible nor viable.

The control and population management of the species is based on the removal of scorpions and the modification of environmental conditions, disfavoring the occurrence, permanence, and proliferation of these animals ${ }^{46}$. The actions of health managers must embrace efforts in urban cleaning, sanitation, public works, and environmental education, while incorporating control measures into the daily life of the population ${ }^{46}$.

In summary, this study reported scorpionism as a serious public health problem in previous years in Alagoas State, Northeast Brazil, with an enormous number of cases occurring from 2007 to 2017. The clinical and epidemiological factors of scorpionism raised in this endemic area can collaborate to health surveillance of scorpion accidents, mainly in tropical and subtropical regions throughout the world. The results have also highlighted the need to establish and/or intensify prevention and education campaigns to avoid scorpion stings that may result in the reduction of its morbidity.

\section{ACKNOWLEDGMENTS}

We would like to thank the support of Teaching Assistance Management at Hospital Escola Dr. Helvio Auto, 
Maceio, Alagoas, Brazil for allowing and approving the data collection for this study. The authors also acknowledge the website https://smart.servier.com used to generate the manuscript Figure 2.

\section{AUTHORS' CONTRIBUTIONS}

LGM, JTS, MBS, LMS, RMBC, SRUV, LA and EJB designed the study, analyzed the data and wrote the manuscript. LGM collected the data. JTS and GSR performed statistical analysis of the data. AAM, CTM, LA and EJB reviewed the manuscript and contributed with the discussion. All the authors reviewed the final version of the manuscript.

\section{CONFLICT OF INTERESTS}

The authors declare that they have no conflict of interests.

\section{ETHICAL APPROVAL}

All the data were based only on secondary data, without access the patients' nominal data or anything else that could identify and following the ethical and legal requirements as requested by Resolution $\mathrm{N}^{\circ} 466 / 12$ from the National Health Council (CNS), Brazil. The data collection for this study was authorized by Teaching Assistance Management at Hospital Escola Dr. Hélvio Auto, Maceió, Alagoas, Brazil.

\section{FUNDING}

JTS has a PhD scholarship from the Fundação de Amparo à Pesquisa do Estado de Alagoas (FAPEAL).

\section{REFERENCES}

1. Santos MS, Silva CG, Neto BS, Grangeiro Júnior CR, Lopes VH, Teixeira Júnior AG, et al. Clinical and epidemiological aspects of scorpionism in the world: a systematic review. Wilderness Environ Med. 2016;27:504-18.

2. Chippaux JP, Goyffon M. Epidemiology of scorpionism: a global appraisal. Acta Trop. 2008;107:71-9.

3. Reckziegel GC, Pinto Junior VL. Análise do escorpionismo no Brasil no período de 2000 a 2010. Rev Pan-Amaz Saude. 2014;5:67-8.

4. Pucca MB, Oliveira FN, Schwartz EF, Arantes EC, Lira-daSilva RM. Scorpionism and dangerous species of Brazil. In: Gopalakrishnakone P, editor. Toxinology. Dordrecht: Springer Netherlands; 2014. p. 1-24.
5. Isbister GK, Bawaskar HS. Scorpion envenomation. N Engl J Med. 2014;371:457-63.

6. Amaral CF, Rezende NA. Both cardiogenic and non-cardiogenic factors are involved in the pathogenesis of pulmonary oedema after scorpion envenoming. Toxicon. 1997;35:997-8.

7. Brasil. Ministério da Saúde. Fundação Nacional de Saúde. Manual de diagnóstico e tratamento de acidentes por animais peçonhentos. $2^{\mathrm{a}}$ ed. Brasília: Ministério da Saúde; 2001. [cited 2020 Apr 14]. Available from: https://www.icict.fiocruz.br/ sites/www.icict.fiocruz.br/files/Manual-de-Diagnostico-eTratamento-de-Acidentes-por-Animais-Pe--onhentos.pdf

8. Brasil. Ministério da Saúde. Sistema de Informação de Agravos de Notificação. Ficha de investigação: acidentes por animais peçonhentos. [cited 2020 Apr 14]. Available from: http:// portalsinan.saude.gov.br/images/documentos/Agravos/AAP/ Animais_Peconhentos_v5.pdf

9. Bouaziz M, Bahloul M, Kallel H, Samet M, Ksibi H, Dammak H, et al. Epidemiological, clinical characteristics and outcome of severe scorpion envenomation in South Tunisia: Multivariate analysis of 951 cases. Toxicon. 2008;52:918-26.

10. Reckziegel GC, Pinto Jr VL. Scorpionism in Brazil in the years 2000 to 2012. J Venom Anim Toxins Incl Trop Dis. 2014;20:46.

11. Barros AH, Araújo Filho JC, Silva AB, Santiago GA. Climatologia do Estado de Alagoas. Recife: Embrapa; 2012.

12. Instituto Brasileiro de Geografia e Estatística. Censo demográfico 2010 : características da população e dos domicílios : resultados do universo. Rio de Janeiro: IBGE; 2010.

13. Zou KH, Tuncali K, Silverman SG. Correlation and simple linear regression. Radiology. 2003;227:617-22.

14. Kim TK. T test as a parametric statistic. Korean J Anesthesiol. 2015;68:540-6.

15. Kao LS, Green CE. Analysis of variance: is there a difference in means and what does it mean? J Surg Res. 2008;144:158-70.

16. McHugh ML. Multiple comparison analysis testing in ANOVA. Biochem Med (Zagreb). 2011;21:203-9.

17. Buckalew LW, Pearson WH. Determination of critical observed frequencies in chi square. Bull Psychon Soc. 1981;18:289-90.

18. Fraas JW, Newman I. A binomial test of model fit. Struct Equ Modeling. 1994;1:268-73.

19. McHugh ML. The chi-square test of independence. Biochem Med (Zagreb). 2013;23:143-9.

20. Yates D, Moore D, McCabe G. The practice of statistics. New York: WH Freeman \& Company; 1999.

21. Brazil TK, Porto TJ. Os escorpiões. Salvador: EDUFBA; 2010.

22. Furtado SS, Belmino JF, Diniz AG, Leite RS. Epidemiology of scorpion envenomation in the State of Ceará, Northeastern Brazil. Rev Inst Med Trop Sao Paulo. 2016;58:15.

23. Lira-da-Silva RM, Amorim AM, Carvalho FM, Brazil. Acidentes por escorpião na cidade do Salvador, Bahia, Brasil TK. Gaz Med Bahia. 2009;79 Supl 1:43-9.

24. Araújo KA, Tavares AV, Marques MR, Vieira AA, Leite RS. 
Epidemiological study of scorpion stings in the Rio Grande do Norte State, Northeastern Brazil. Rev Inst Med Trop Sao Paulo. 2017;59:e58.

25. Mesquita FN, Nunes MA, Santana VR, Machado Neto JM, Almeida KB, Lima SO. Acidentes escorpiônicos no estado do Sergipe - Brasil. Rev Fac Cienc Med Sorocaba. 2015;17:15-20.

26. Almeida TS, Fook SM, França FO, Monteiro TM, Silva EL, Gomes LC, et al. Spatial distribution of scorpions according to the socioeconomic conditions in Campina Grande, State of Paraíba, Brazil. Rev Soc Bras Med Trop. 2016;49:477-85.

27. Barbosa AL. Tendências nas horas dedicadas ao trabalho e lazer: uma análise da alocação do tempo no Brasil. Rio de Janeiro: IPRA; 2018.

28. Lourenço WR. What do we know about some of the most conspicuous scorpion species of the genus Tityus? A historical approach. J Venom Anim Toxins Incl Trop Dis. 2015;21:20.

29. Costa CL, Fé NF, Sampaio I, Tadei WP. A profile of scorpionism, including the species of scorpions involved, in the State of Amazonas, Brazil. Rev Soc Bras Med Trop. 2016;49:376-9.

30. Nunes CS, Bevilacqua PD, Jardim CC. Aspectos demográficos e espaciais dos acidentes escorpiônicos no Distrito Sanitário Noroeste, Município de Belo Horizonte, Minas Gerais, 1993 a 1996. Cad Saude Publica. 2000;16:213-23.

31. Levorato CD, Mello LM, Silva AS, Nunes AA. Fatores associados à procura por serviços de saúde numa perspectiva relacional de gênero. Cien Saude Coletiva. 2014;19:1263-74.

32. Gomes R, Nascimento EF, Araújo FC. Por que os homens buscam menos os serviços de saúde do que as mulheres ? As explicações de homens com baixa escolaridade e homens com ensino superior. Cad Saude Publica. 2007;23:565-74.

33. Lourenço WR, Cuellar O. Scorpions, scorpionism, life history strategies and pathernogenesis. J Venom Anim Toxins. 1995;1:51-62.

34. Zanella DP, Valadão AF, Arêdes CA, Campos GC, Cordeiro ND, Spencer PJ. Escorpionismo no Vale do Aço, Minas Gerais. Braz J Surg Clin Res. 2018;23:60-6.

35. Soares MR, Azevedo CS, De Maria M. Escorpionismo em Belo Horizonte, MG: um estudo retrospectivo. Rev Soc Bras Med Trop. 2002;35:359-63.

36. Barbosa AD, Magalhães DF, Silva JA, Silva MX, Cardoso MF, Meneses JN, et al. Caracterização dos acidentes escorpiônicos em Belo Horizonte, Minas Gerais, Brasil, 2005 a 2009. Cad Saude Publica. 2012;28:1785-9.

37. Bahloul M, Chabchoub I, Chaari A, Chtara K, Kallel H, Dammak $\mathrm{H}$, et al. Scorpion envenomation among children: Clinical manifestations and outcome (analysis of 685 cases). Am J Trop Med Hyg. 2010;83:1084-92.
38. Santos JM, Croesy GS, Marinho LF. Perfil epidemiológico dos acidentes escorpiônicos em crianças, no estado da Bahia, de 2007 a 2010. Rev Enferm Contemp. 2012;1:118-29.

39. Bosnak M, Ece A, Yolbas I, Bosnak V, Kaplan M, Gurkan F. Scorpion sting envenomation in children in southeast Turkey. Wilderness Environ Med. 2009;20:118-24.

40. Khatony A, Abdi A, Fatahpour T, Towhidi F. The epidemiology of scorpion stings in tropical areas of Kermanshah province, Iran, during 2008 and 2009. J Venom Anim Toxins Incl Trop Dis. 2015;21:45.

41. D’Suze G, Moncada S, González C, Sevcik C, Aguilar V, Alagón A. Relationship between plasmatic levels of various cytokines, tumour necrosis factor, enzymes, glucose and venom concentration following Tityus scorpion sting. Toxicon. 2003;41:367-75.

42. Brasil. Ministério da Saúde. Gabinete do Ministro. Portaria ${ }^{\circ}$ 204, de 17 de fevereiro de 2016. Define a Lista Nacional de Notificação Compulsória de doenças, agravos e eventos de saúde pública nos serviços de saúde públicos e privados em todo o território nacional, nos termos do anexo, e dá outras providências. [cited $2020 \mathrm{Apr}$ 14]. Available from: https:// portalarquivos2.saude.gov.br/images/pdf/2018/abril/25/ Portaria-n---2014-de-17--Fevereiro-2016.pdf

43. Pinheiro RS, Andrade VL, Oliveira GP. Subnotificação da tuberculose no Sistema de Informação de Agravos de Notificação (SINAN): abandono primário de bacilíferos e captação de casos em outras fontes de informação usando linkage probabilístico. Cad Saude Publica. 2012;28:1559-68.

44. Lafetá KR, Martelli Júnior H, Silveira MF, Paranaíba LM. Maternal and congenital syphilis, underreported and difficult to control. Rev Bras Epidemiol. 2016;19:63-74.

45. Lacerda KM, Fernandes RC, Nobre LC. Acidentes de trabalho fatais em Salvador, BA: descrevendo o evento subnotificado e sua relação com a violência urbana. Rev Bras Saude Ocup. 2014;39:63-74.

46. Brasil. Ministério da Saúde. Secretaria de Vigilância em Saúde. Departamento de Vigilância Epidemiológica. Manual de controle de escorpiões. Brasília: Ministério da Saúde; 2009.

47. Lourenço WR. Scorpions and life-history strategies: from evolutionary dynamics toward the scorpionism problem. J Venom Anim Toxins Incl Trop Dis. 2018;24:19. 


\section{SUPPLEMENTARY MATERIAL}

\section{S.1 - SINAN NOTIFICATION FORM (SNF)}

https://portalsinan.saude.gov.br/images/documentos/Agravos/AAP/Animais_Peconhentos_v5.pdf

\section{República Federativa do Brasi} Ministério da Saúde
SINAN

SISTEMA DE INFORMACCÃO DE AGRAVOS DE NOTIFICAÇÃO FICHA DE INVESTIGAÇÃO

\section{ACIDENTES POR ANIMAIS PEÇONHENTOS}

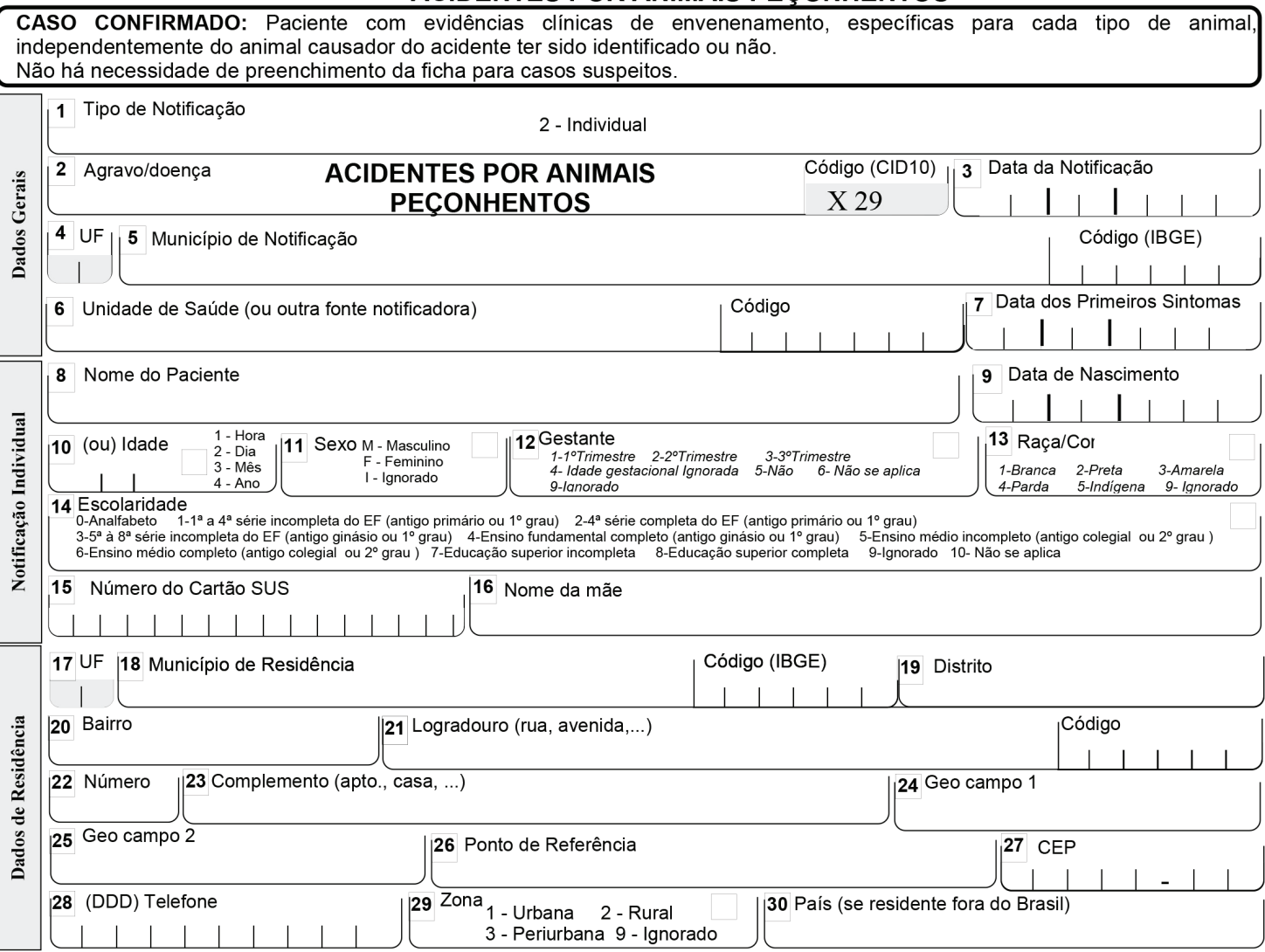

\section{Dados Complementares do Caso}

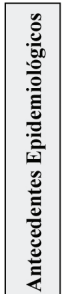

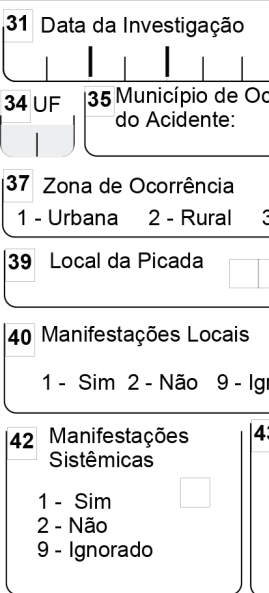

32 Ocupação

33 Data do Acidente

Localidade de Ocorrência do Acidente:

38 Tempo Decorrido Picada/Atendimento

- Periurbana 9 -Ignorado

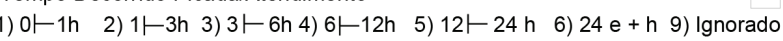

01 - Cabeça 02 - Braço

03 - Ante-Braço 04 - Mão

10 - Dedo do Pé $\quad 95$ - Dedo da Mão

41 Se Manifestações Locais Sim, especificar: 1 - Sim 2 - Não 0 - Ignorado

45 Tipo de Acidente

5 - Abelha

2 - Aranha

47 Aranha - Tipo de Acidente

1 - Foneutrismo

2 - Loxoscelismo

Dor $\quad$ Edema

Equimose

Necrose

Outras (Espec.)

4 - Outra Aranha 9 - Ignorado
3 - Escorpião

4 - Lagarta

3 - Latrodectismo

\section{specificar: 1 - Sim 2 - Não
hemorrágicas (gengivorragia, outros sangramentos)}

neuroparalíticas (ptose palpebral, turvação visual

miolíticas/hemolíticas (mialgia anemia, urina escura)

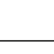

3-Latrodectismo

Sinan Net

- Ignorado
vagais (vômitos,
diarréias)
Outras (Espec.)

$\mid \begin{aligned} & \mathbf{4 4} \begin{array}{l}\text { Tempo de } \\ \text { Coagulação } \\ 1\end{array} \\ & 2 \text { - Normal } \\ & 2 \text { - Alterado } \\ & 9 \text { - Não } \\ & \text { realizado }\end{aligned}$

46 Serpente - Tipo de Acidente

1 - Botrópico 2 - Crotálico 3 - Elapídico 4 - Laquético

5 -Serpente Não Peçonhenta 9 - Ignorado

48 Lagarta - Tipo de Acidente

1 - Lonomia 2 - Outra lagarta 9 -Ignorado 


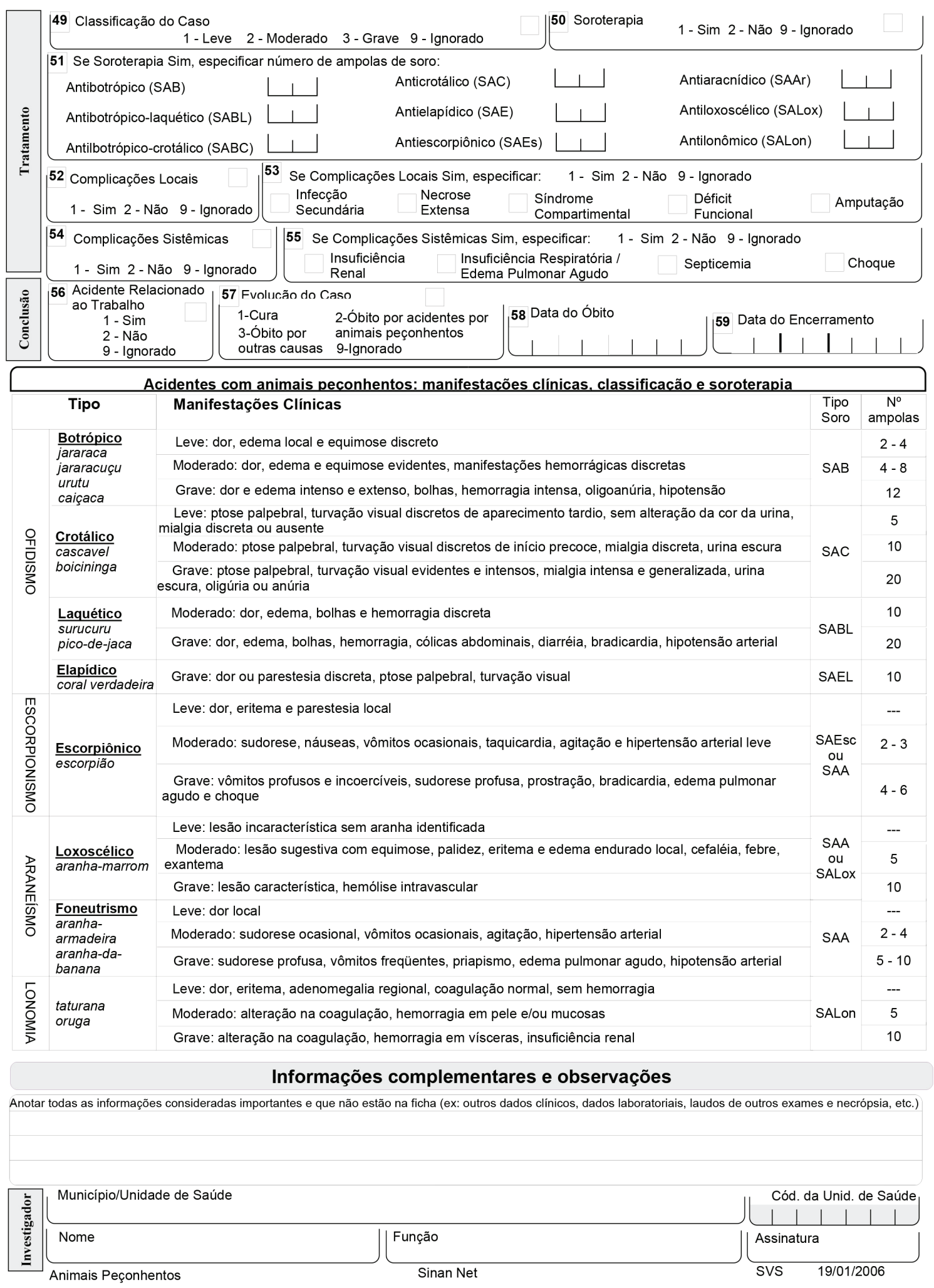




\section{S.2 - VARIABLES INCLUDED INTHE STATISTICAL ANALYSES}

\section{DESCRIPTIVE STATISTICS (ABSOLUTE NUMBER AND PERCENTAGE):}

\section{Sociodemographic characteristics}

- Year of occurrence

- $2007,2008,2009,2010,2011,2012,2013$, 2014, 2015, 2016, 2017

- Month of occurrence

- 01 - January (Jan)

○ 02 - February (Feb),

- 03 - March (Mar),

- 04 - April (Apr),

○ 05 - May (May),

- 06 - June (Jun),

○ 07 - July (Jul),

- 08 - August (Aug),

- 09 - September (Sep),

- 10 - October (Oct),

- 11 - November (Nov),

- 12 - December (Dec)

\section{- Age range}

The patient's age was calculated from the date of birth and the date of the accident, generating a continuous variable that was categorized into age groups.

$0<1$-year-old to 4-years-old

o 5- to 9-years-old

- 10- to 14-years-old

- 15- to 19-years-old

o 20- to 29-years-old

- 30- to 39-years-old

- 40- to 49-years-old

- 50- to 59-years-old

- 60- to 69-years-old

- 70- to 79-years-old

o 80-years-old or more

- Accident zone

- Urban

- Peri-urban

○ Rural

- Skin color/Ethnicity

o White

- Black

- Asian (yellow - East Asians)

- Multiracial ("pardo" - mixed ethnic ancestries)

- Indigenous (Amerindians)

\section{- Education level}

Based in the law and guidelines and bases of Brazilian national education in force during the study period (available at http://www.planalto. gov.br/ccivil_03/Leis/L9394.htm)

- Unlettered

- Uncomplete primary school

- $1^{\text {st }}$ grade (complete or incomplete),

- $2^{\text {nd }}$ grade (complete or incomplete),

- $3^{\text {rd }}$ grade (complete or incomplete),

- $4^{\text {th }}$ grade (incomplete)

- Complete primary school

- $4^{\text {th }}$ grade (complete)

- Uncomplete elementary school

- $5^{\text {th }}$ grade (complete or incomplete),

- $6^{\text {th }}$ grade (complete or incomplete),

- $7^{\text {th }}$ grade (complete or incomplete),

- $8^{\text {th }}$ grade (incomplete)

- Complete elementary school

- $8^{\text {th }}$ grade (complete)

- Uncomplete high school

- $10^{\text {th }}$ grade (complete or incomplete)

- $11^{\text {th }}$ grade (complete or incomplete)

- $12^{\text {th }}$ grade (incomplete)

- Complete high school

- $12^{\text {th }}$ grade (complete)

- Uncomplete higher education

- Complete higher education

- Not applicable

- Ignored/Omitted

\section{Clinical characteristics}

\section{- Severity}

- Mild - pain, erythema and local paresthesia

- Moderate - sweating, nausea, occasional vomiting, tachycardia, agitation and mild arterial hypertension

- Severe - profuse and incoercible vomiting, profuse sweating, prostration, bradycardia, acute pulmonary edema and shock

\section{- Sting location}

- Head

- Arm

- Forearm

- Hand

- Finger

- Torso

- Leg

○ Thigh

- Foot

○ Toe 
- Occurrence of local manifestations Yes or No

- Occurrence of systemic manifestations Yes or No

- Serotherapy

Yes or No

- Time between the sting and the medical care

$0<1$ hour

- 1 to 3 hours

- 3 to 6 hours

- 6 to 12 hours

- 12 to 24 hours

- 24 hours

\section{S.3 STATISTICAL TESTS:}

1) Student T-test (unpaired samples):

- Gender (Female vs. Male cases per year) p-value: $<0.0001$

2) One-way ANOVA (Tukey's multiple comparisons test - post hoc test):

- Month of occurrence - p-value: 0.4977

3) Part of a whole - Observed distribution with expected cases comparison:

The expected percentage for the population of Alagoas (Brazil) was obtained from 2010 Brazilian Census.

\section{Gender}

\begin{tabular}{ccc}
\hline Gender & $\begin{array}{c}\text { Observed } \\
\text { cases }\end{array}$ & $\begin{array}{c}\text { Expected } \\
\text { (IBGE, 2010) }\end{array}$ \\
\hline Male & 10,693 & $48.45 \%$ \\
Female & 17,295 & $51.55 \%$ \\
\hline
\end{tabular}

- Test: Binomial Test

- p-value: $<0.0001$

- Conclusion: The discrepancy is significant
Age Range

\begin{tabular}{ccc}
\hline Age Range & $\begin{array}{c}\text { Observed } \\
\text { cases }\end{array}$ & $\begin{array}{c}\text { Expected } \\
\text { (IBGE, 2010) }\end{array}$ \\
\hline 1- to 4-years-old & 2,236 & $8.72 \%$ \\
5- to 9-years-old & 2,399 & $9.62 \%$ \\
10- to 14-years-old & 2,290 & $10.84 \%$ \\
15- to 19-years-old & 2,357 & $10.03 \%$ \\
20- to 29-years-old & 4,742 & $18.01 \%$ \\
30- to 39-years-old & 4,156 & $14.69 \%$ \\
40- to 49-years-old & 3,614 & $11.37 \%$ \\
50- to 59-years-old & 2,882 & $7.86 \%$ \\
60- to 69-years-old & 1,973 & $5.02 \%$ \\
70- to 79-years-old & 986 & $2.63 \%$ \\
80-years-old or more & 353 & $1.23 \%$ \\
\hline
\end{tabular}

- Test: Chi-square for goodness of fit

- Chi-square test: 908.5

- Degrees of freedom: 10

- p-value: $<0.0001$

- Conclusion: The discrepancy is significant

Accident Zone

\begin{tabular}{ccc}
\hline Accident zone & $\begin{array}{c}\text { Observed } \\
\text { cases }\end{array}$ & $\begin{array}{c}\text { Expected } \\
\text { (IBGE, 2010) }\end{array}$ \\
\hline Urban & 26,494 & $73.60 \%$ \\
Peri-urban or Rural & 489 & $26.40 \%$ \\
\hline
\end{tabular}

Ignored/Omitted: 1,005 cases

- Test: Binomial Test

- p-value: $<0.0001$

- Conclusion: The discrepancy is significant

Skin color/Ethnicity

\begin{tabular}{ccc}
\hline $\begin{array}{c}\text { Skin colorl } \\
\text { Ethnicity }\end{array}$ & $\begin{array}{c}\text { Observed } \\
\text { cases }\end{array}$ & $\begin{array}{c}\text { Expected } \\
\text { (IBGE, 2010) }\end{array}$ \\
\hline White & 1,426 & $31.61 \%$ \\
Black & 1,243 & $6.57 \%$ \\
Asian & 16 & $1.18 \%$ \\
Multiracial & 24,858 & $60.18 \%$ \\
Indigenous & 25 & $0.46 \%$ \\
\hline
\end{tabular}

- Test: Chi-square for goodness of fit

- Chi-square test: 10770

- Degrees of freedom: 4

- p-value: $<0.0001$

- Conclusion: The discrepancy is significant 
4) Chi-square test for independence:

\section{Systemic manifestations vs:}

Not Included (Variables whose expected count value of one fifth of categories was less than 5):

- Skin color/Ethnicity - $20 \%$ of expected counts were $<5$

- Accident zone $-16,7 \%$ of expected counts were $<5$

- Evolution - $66.7 \%$ of expected counts were $<5$

\section{Included}

No association with the occurrence of systemic manifestations ( $p$-value $>0.05$ )

- Sting location:

- $\chi^{2}=15.480$

- Degrees of freedom: 9

- $p$-value $=0.079$

- Gender:

- $\chi^{2}=0.053$

- Degrees of freedom: 1

- $p$-value $=0.819$

\section{Association with systemic manifestations:}

Age range (years):

- $\chi^{2}=1007.956$

- Degrees of freedom: 11

- $\mathrm{p}$-value $<0.0001$

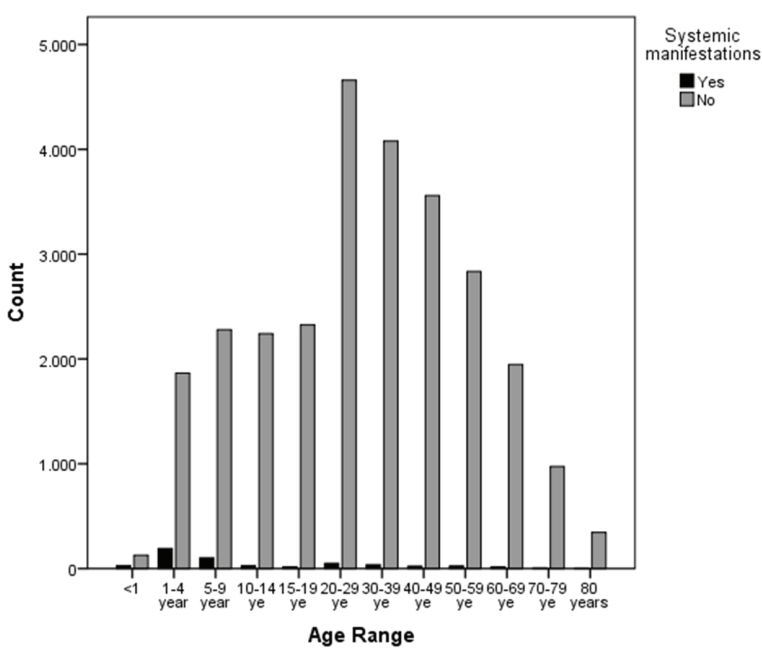

Time between the sting and the medical care:

- $\chi^{2}=98.832$

- Degrees of freedom: 5

- $\mathrm{p}<0.0001$

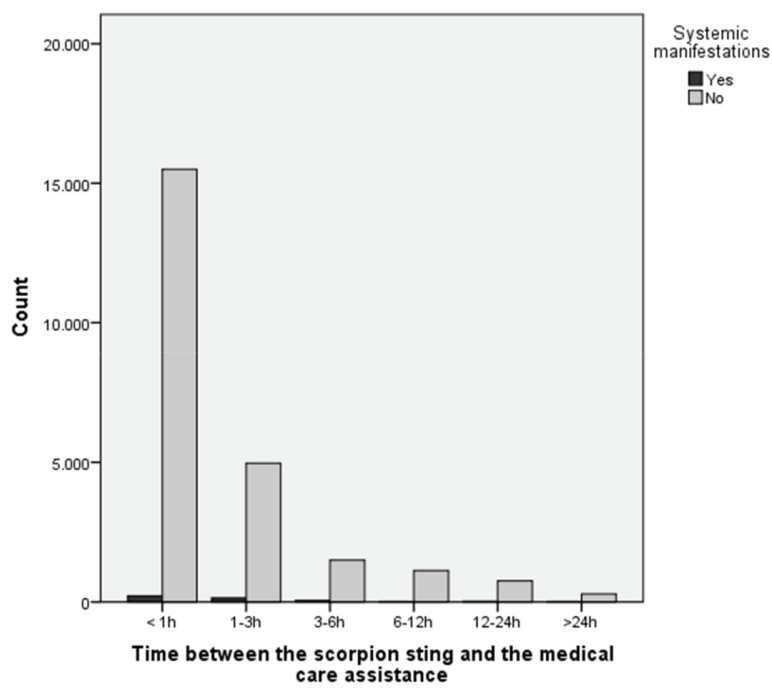

Association of Severity with Age Range

- $\chi^{2}=1328.604$

- Degrees of freedom: 22

- $\mathrm{p}<0.0001$

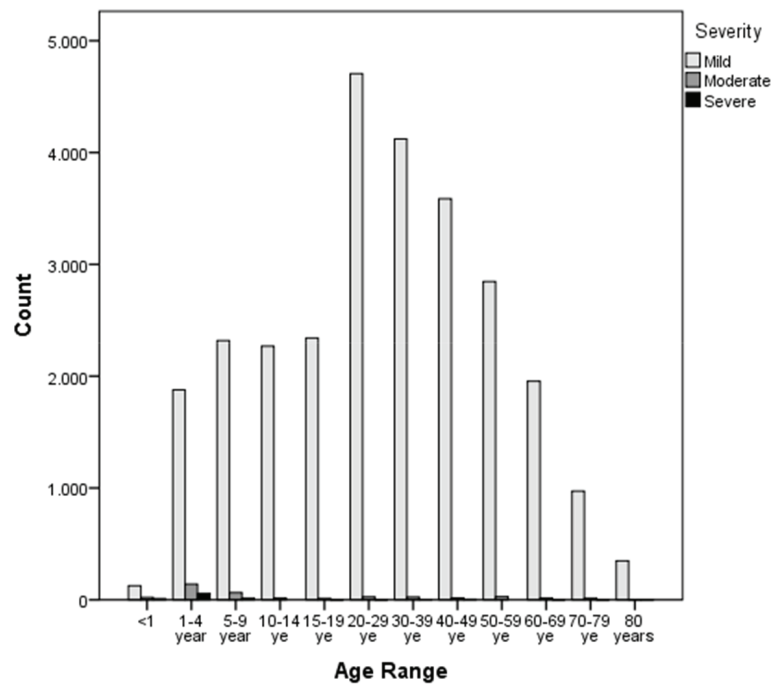

